\section{The books of the dead revisited: mortality and morbidity in the German colonies of southern Brazil, 1850-1880}

\author{
Revisitando os livros dos \\ mortos: mortalidade e \\ morbidade nas colônias \\ alemãs do sul do Brasil, \\ 1850-1880
}

\section{João Biehl}

Department of Anthropology, Program in Global Health, and Brazil LAB/Princeton University. Princeton - NJ - USA

jbiehl@princeton.edu

\section{Miquéias Henrique Mugge \\ Brazil LAB/Princeton University. \\ Princeton - NJ - USA \\ mmugge@princeton.edu}

\section{Ana Maria Goldani \\ Brazil LAB/Princeton University. \\ Princeton - NJ - USA \\ anamariagoldani@gmail.com}

Received on 22 Nov. 2017.

Approved on 25 Jan. 2018
BIEHL, João; MUGGE, Miquéias

Henrique; GOLDANI, Ana Maria. The books of the dead revisited: mortality and morbidity in the German colonies of southern Brazil, 1850-1880. História, Ciências, Saúde-Manguinhos, Rio de Janeiro, v.25, n.4, out.-dez. 2018, p.11971217.

Abstract

Examines mortality and morbidity in São Leopoldo/RS (1850-1880). Our interdisciplinary study is based on the Gemeindebücher (parish registers) produced by Lutheran communities. These "community books" reveal high rates of fertility and premature death. Infant mortality and maternal death assailed everyday life. Over half of all deaths were of infants and children. Of ten funerals, seven were for children and adults of reproductive and military age. This article contributes to debates over environmental, social and political determinants of mortality and people's arts of living and healing in protostatistical Brazil.

Keywords: infant mortality and maternal death; German immigration; Lutheran parish registers; Mucker War; protostatistical Brazil.

Resumo

Trata de morbidade e mortalidade em São Leopoldo/RS (1850-1880). Nosso estudo interdisciplinar se baseia nos Gemeindebücher (registros paroquiais) de comunidades luteranas. A análise deles revela altos índices de fertilidade e de mortes prematuras. Elevadas taxas de mortalidade materna e infantil marcavam o cotidiano. De todas as mortes, mais da metade delas eram crianças (0-14 anos). Sete em cada dez funerais eram de crianças (0-14 anos) $e$ de adultos jovens (15-39 anos), retrato da precariedade das condições de vida. $O$ artigo contribui para debates sobre os determinantes sócio-políticos e ambientais da mortalidade em áreas rurais. Por fim, trata das artes de viver e curar no Brasil proto-estatístico.

Palavras-chave: morte infantil e materna; imigração alemã; registros paroquiais luteranos; Guerra dos Muckers; Brasil protoestatístico. 


\section{Introduction}

As we carefully combed through the fragile yellowed pages of the parish registers of the Lutheran community of Picada Café (founded in 1851), we were dumbfounded by the high number of recorded child deaths in this frontier settlement, part of the German Colony of São Leopoldo in the Province of Rio Grande do Sul. A death on October 10, 1855, was particularly striking: the infant Elisabeth Dahmer, daughter of Carl Dahmer and Anna Maria Möbus, had been buried "unbaptized for she lived only three hours." Not the local lay pastor August Sintz, but "women from the neighborhood" had buried little Elisabeth in the communal cemetery next to the house of worship. Earlier that year, the same young couple had buried their firstborn, Catharina Philippine, another infant fatality. We wondered how widespread child mortality was in this rural region, how peasant families dealt with disease and the menace of death, and how they grieved and lived on. Struck by this community's conscientious recordkeeping, we embarked on a systematic study of mortality and morbidity in the nineteenth century German settlements that entered history as Brazil's first postIndependence large-scale immigrant colonization experiment. ${ }^{1}$

In this essay, we present the realities of child and adult death among Lutheran communities in the northern settlements of São Leopoldo Colony between 1850-1880 (with a focus on Sapiranga, Campo Bom, Dois Irmãos, São José do Hortêncio, Picada 48, and Picada Café) ${ }^{2}$ (Hillebrand, 1924). We also discuss how death and morbidity affected people's everyday lives, survival strategies, and health-seeking and religious practices. ${ }^{3}$

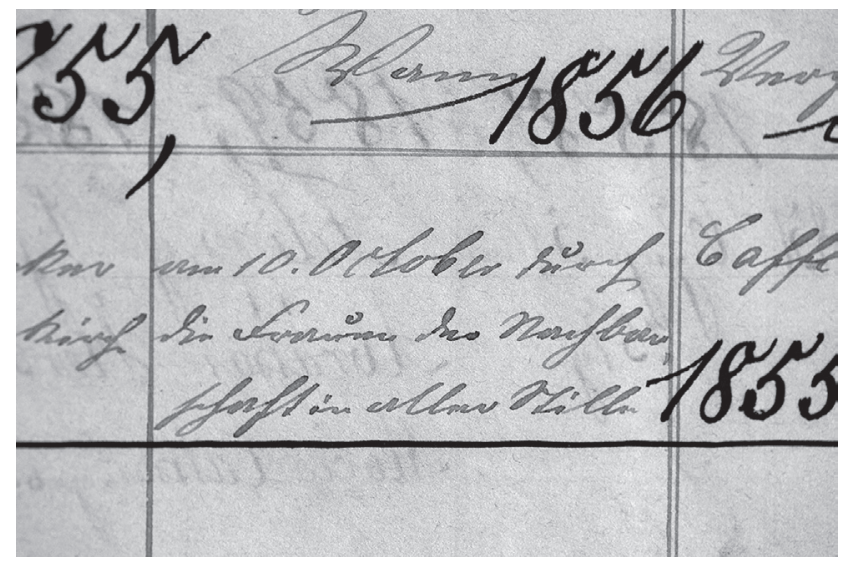

Figure 1: Death registry of Elisabeth Dahmer, October 10, 1855, Picada Café parish register (Courtesy of Torben Eskerod)

Historical demographers have shown that a sustained decrease in infant and child mortality was a major contributor to the overall decline in Western Europe's mortality rates in the eighteenth and nineteenth centuries, playing a key role in the increase of average life expectancy and subsequent demographic regime shifts (Vögele, Woelk, 2002, p.587; Mühlichen, Scholz, Doblhammer, 2015). The debate over a causal relationship between economic prosperity and infant mortality levels, however, is far from settled. A growing number of scholars suggest that "a vast number of interrelated factors" (Edvinsson, 
Gardarsdóttir, Thorvaldsen, 2008, p.457) shape the survival chances of infants, and that numerous features (such as geography, social class, ethnicity, literacy, religion, customs) make it difficult "to explain differences between countries and regions" (Glavatskaya, Borovik, Thorvaldsen, 2017, p.2). Infant and child mortality and maternal deaths are important indicators of social and economic conditions at both regional and countrywide levels (Fogel, 1994; Glavatskaya et al., 2017). While they speak to the local availability and quality of health care, they also shed light on the nature of social inequalities, including gender bias and racial disparities (Sen, 1998).

These debates over the environmental, social and structural determinants of mortality and the heterogeneity of life prospects inform our foray into the largely understudied subject of mortality in the nineteenth-century Brazilian countryside. In what follows, we present our initial findings (with a special focus on infant mortality and maternal death) and reflect on patterns and differences at local and regional levels. Our investigation is based on a source still little known to Brazilian historiography: the parish registers - Gemeindebücher, "community books" (or livros antigos da igreja, old church books, in today's parlance) - of Lutheran congregations.

\section{Archives of proto-statistical Brazil}

Social historians and historical demographers have called for sustained engagements with Brazilian Catholic parish registers. Given the absence of official population-wide censuses for most of the nineteenth century and the disappearance of notary records, these registers are rich resources for the characterization of local worlds and our understanding of regional diversities in the country. According to João Fragoso (2014), the seriality and sheer volume of parish registers of baptisms, marriages, and burials allow scholars of Catholic societies to meticulously document family alliances, patronage networks, and the influx of slaves and immigrants, along with people's patterns of residence and mobility. Ana Silvia Volpi Scott (2012) has championed the use of Catholic parish registers to identify different demographic regimes within the Brazilian population, with a focus on fertility patterns and the reality of social endogamy among both emigrant communities in Portugal and immigrant communities in the state of Rio Grande do Sul. Sergio Nadalin $(1974 ; 2014)$, in turn, has pioneered the study of non-Catholic parish registers, analyzing naming practices as markers of ethnic identity of Lutheran communities in Paraná.

Hitherto, child mortality has received little attention in populational studies of eighteenth and nineteenth century Brazil. Historians and demographers link this dearth of studies to the absence of census data and time series for these periods. They also allude to the general imprecision of age registries and to the underreporting of child deaths in the Catholic parish registers which have become the default source for the few studies available (Burmester, 1986, p.296-306; Costa, 1976; Campos, 2011). In contrast, the Lutheran parish registers that we use in our study reveal a more rigorous mode of recordkeeping. For these small communities, vital registries were integral to social belonging and status. At times, parishioners even used them as para-legal evidence in claims over inheritance. Unlike the Catholic populations of the interior of the country, which for the most part did not 
have a clergyman in residence and received only sporadic pastoral assistance (Pereira das Neves, 2009), each set of Lutheran communities had its own pastor in charge of services and recordkeeping (Hunsche, 1983; Witt, 2015). And, as we found in our study, even in the eventual absence of a pastor, community members (such as schoolmasters) had access to the Gemeindebuch to register a person's death and burial. In most of the parish registers studied, we also noticed that the person's age at death was by and large recorded fairly accurately (in days, months, and years). This was most likely a tradition early immigrants brought from Germany where, given the absence of a civil registry, Lutheran records were of an official nature. ${ }^{4}$ The consistent and precise patterns of Lutheran recordkeeping thus leave us with a fairly representative picture of vital events in these frontier settlements.

There is a general lack of official data on the population of this rural region, and the results of the first Brazilian census of 1872 for São Leopoldo are problematic to say the least (Paiva et al., 2012). A close scrutiny of the census results reveals deep and glaring flaws: in the majority-Protestant settlement of Dois Irmãos, for example, all residents were considered "Catholic" (Hillebrand, 1924; Mugge, 2012, p.142-143). Given this lacuna, the Lutheran parish registers serve as a key source for understanding the demographic regimes of this proto-statistical settler population (from people's patterns of fertility and mortality to patterns of social endogamy and internal migration) (Nadalin, 1974; 2014; 2012). These registries occasionally also included significant qualitative information, such as presumed causes of death, burial practices, and moral judgements (from references to virginity and alcoholism to good neighborliness) (Blume, 2015). Mostly initiated by the settlers themselves, the Lutheran communal records can thus also be seen as "anthologies of existences" of sorts (Foucault, 2000, p.155), through which we can get glimpses of people's systems of reference and of "the true harshness of reality" they faced (Farge, 2013, p.86).

The majority of the German-Brazilian scholarship has critically explored the development and social life of the São Leopoldo colonial headquarters and its more affluent surrounding settlements (Roche, 1969; Amado, 1978; Tramontini, 2000). By juxtaposing community sources from old satellite settlements (Campo Bom, Dois Irmãos, and Hortêncio, populated in the 1820s and 1830s) with new peripheral sites (Picada 48, Picada Café, and Sapiranga, populated in the 1840s and 1850s), our mortality and morbidity study thus also provides a more diverse characterization of the German-Brazilian population of the time, with an eye towards biosocial realities and cultural practices.

The northern settlements of the São Leopoldo Colony are also of particular historical significance because of the therapeutic and charismatic movement known as Mucker (literally, those who dig muck: who are false saints, sanctimonious and hypocritical), which originated in Sapiranga. Most of the families who made up the movement and who gathered around the trances and scriptural readings of Jacobina Mentz and the herbal medicines prepared by her husband João Jorge Maurer lived in this northern region and were members of Lutheran communities (Amado, 1978, p.135; Biehl, 1996a; Dreher, 2017). In the summer of 1874 , after a year of intense intra-ethnic conflict in the region, approximately one hundred settlers were hunted down and killed by armed neighbors and the Brazilian National Army (Petry, 1957; Domingues, 1977; Biehl, 1999; Dickie, 1996). We suspected that the specter of death would be a powerful actor in this context - a driving force leading 
a growing number of people to the Maurers' in search of healing and care - and decided to probe this hypothesis in our systematic analysis of mortality patterns and explorations of causes of death in the peripheral Sapiranga and other northern settlements.

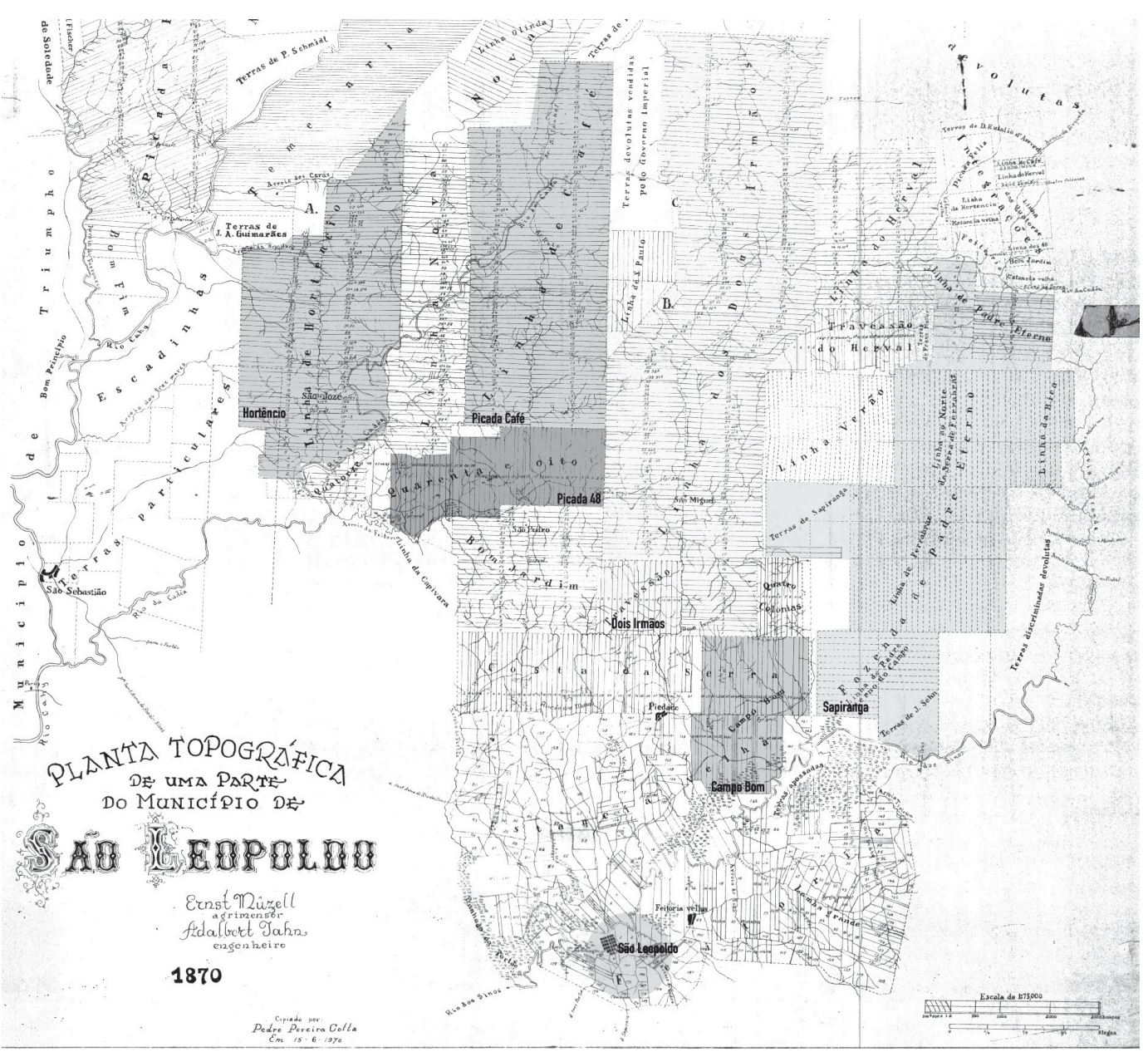

Figure 2: Map of São Leopoldo and northern settlements (created by Müzell [1870] and redesigned by the authors)

\section{Historical sources and methods}

The Colony of São Leopoldo was founded in 1824, as the result of an imperial project to secure the contested borderlands and promote farming based on free labor (Roche, 1969; Hunsche, 1975; Seyferth, 1982; Witt, 2015). This colonial experiment was put on hold during the bloody secessionist Farroupilha civil war (1835-1845), and immigration to the Province resumed immediately thereafter (Tramontini, 2000). In the following years, São Leopoldo experienced fast economic growth and territorial expansion following the arrival of a new wave of German immigrants, intense internal migration and land speculation (Amado, 1978). While in 1845, the larger São Leopoldo colonial region had 7,142 German-Brazilian 
inhabitants, by 1857 there were some 12,500 settlers living there - a 75\% population increase in little over a decade (Amado, 1978, p.65; Mugge, 2012, p.60-63). The number of enslaved people also increased over the years. In 1858, a local census reported the presence of 1,804 captives, making up about $10 \%$ of the total estimated population (Moreira, Mugge, 2014).

Numerous Catholic churches and Lutheran houses of worship were built throughout the colonial region during this period (Amado, 1978, p.110; Hunsche, 1983). Although the Roman Catholic Apostolic Religion remained the official religion of the independent Brazilian empire, and was in charge of all civil registries in the country, other religions were allowed to hold "domestic or private worship in houses designed for this, which do not have the exterior form of a temple" (Brasil, 25 mar. 1824) According to the annual report of the President of the Province João Lins Sinimbu, by 1854, São Leopoldo already had "twenty-one churches in the territory, nine of the Catholic creed and twelve Protestant." While the Provincial government paid for a very limited number of ordained Lutheran pastors to work in the colonial headquarters of São Leopoldo and the nearby settlements of Hamburgo Velho and Campo Bom, the newer communities elected their own lay ministers, many of whom were educated farmers and schoolmasters (Hunsche, 1983). The first German Jesuit missionaries arrived in the region in the late 1840s, followed by the German Lutheran missionaries in the mid-1860s (Biehl, 1996b; Dreher, 1984). ${ }^{6}$

We visited six Lutheran congregations in the São Leopoldo colonial region as well as the main archive of the Brazilian Lutheran Church (IECLB). The Gemeindebücher are stored in the offices or pastoral homes of these local parishes. We photographed the books in order to carry out this study. We were unable to locate the original book from São José do Hortêncio, but had access to a transcribed copy. ${ }^{7}$

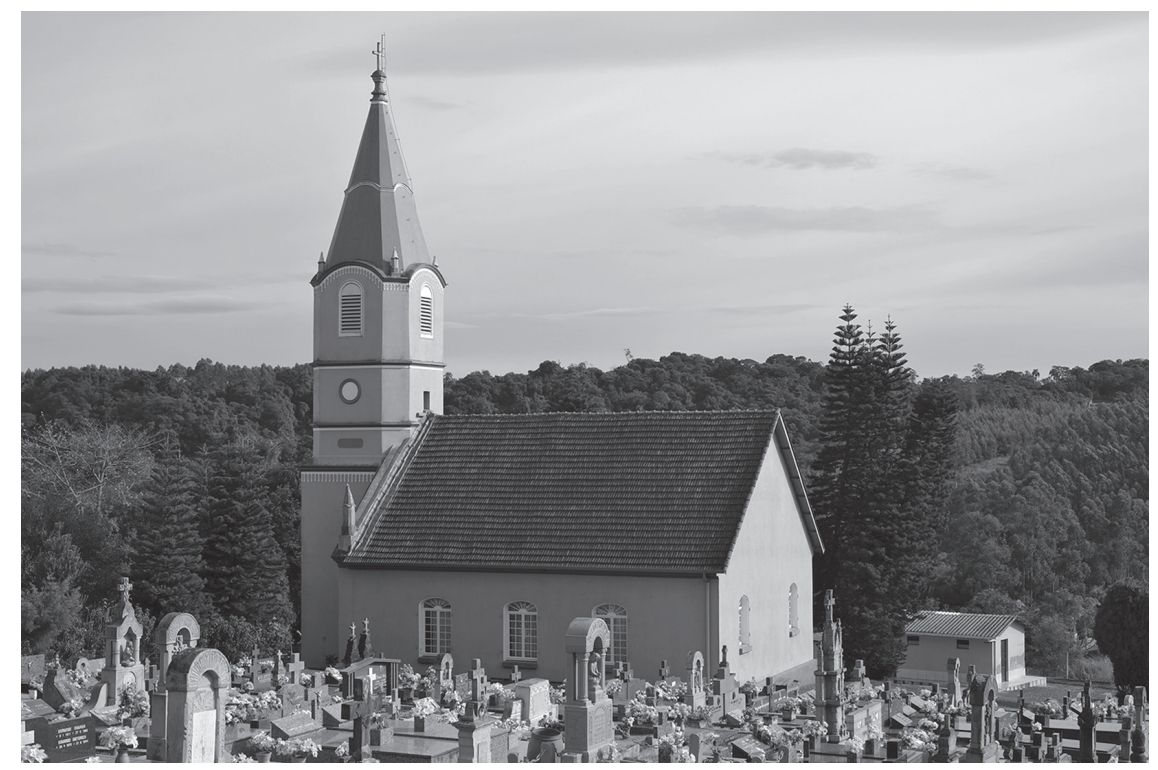

Figure 3: Lutheran Church of Picada 48, inaugurated in 1850, with tower added in 1901 (Courtesy of Miqueias H. Mugge). 
These precious grassroots historical records have been preserved to various degrees. Most are kept in overcrowded cabinets, without any special preservation efforts, just one among dozens of other parish registers and accounting books. While analyzing these old church books, we noticed signs of mishandling, such as signposting on the margins, in addition to the wear and tear that comes with their handling by nonspecialists, especially families eager to trace their genealogies (as several local church administrators told us).

The opening pages of these Lutheran registers provide a wide array of information about the history these communities: bylaws, names of founding members and councilmen, lists of donors and donations for the construction of the Bethaus (literally, house of prayer). These independent communities shared ideas, practices and information among themselves, and also mimetically assimilated the knowhow from older congregations, such as São Leopoldo, Hamburgo Velho, and Campo Bom. There was no centralized religious institution unifying these religious communities.

Although congregations experienced pastoral rotation, the shifts were not formally noted in the registers and can only be identified by changes in handwriting. Consider the congregation of Picada 48, which was founded in 1850 by the lay pastor Christian August Sintz, who worked there until 1859. Upon his passing, the congregation was guided by the lay pastor João Jorge Klein, later associated with the Mucker (Petry, 1957; Domingues, 1977), who had himself founded the congregation of Sapiranga the year before. In 1864 , Klein was replaced by Johannes Stanger, one of the many ordained German pastors who would, in the coming decades, transform the colonies into a new missionary frontier (Biehl, 1996a; Wachholz, 2003; Hunsche, 1983). The parish registers are a rare material reminder of the self-governance, adaptability, and late "germanization" of these largely illiterate (or semi-literate) communities. ${ }^{8}$

The main purpose of the Gemeindebuch was to record the life events of families in the community: birth/baptism, youth confirmation, marriage, and death/burial. Local pastors wrote the entries in Gothic German, based on information retrieved from parishioners and their kin (including a child's godparents, "compadres" and "comadres"). The actual registration did not always follow a systematic pattern. In some books, all events are listed chronologically, while in others, they are listed under categories (baptisms, marriages etc.). We noticed a concern with completeness in recordkeeping, as pastors often inscribed events retroactively (especially when they were unable to perform the rituals themselves) with the aid of other literate community members.

The first German immigrants recorded baptisms, marriages, and deaths during their transatlantic journey to the new world. This registry became the first "church book" of the São Leopoldo Lutheran community. In the majority of German territories, there was no civil registration, and congregations were therefore in charge of the work of recordkeeping (Lee, Marschalk, 2002). In Brazil, immigrants would continue this form of community recordkeeping. In 1848, when the lay pastor Christian Sintz started the Picada 48 parish register, he even named it the book of Zivilstand (civil status). This customary practice affirmed people's religious identity and communal belonging, while also carrying potential legal value. 
Lutheran communities also copied the registration practices of Brazil's official religion. Extending Portuguese colonial practices, each Catholic parish had to keep a registry of its members. Priests had to follow specific norms of registration: this system had been defined and standardized by the First Constitutions of the Bahian Archbishopric (1707), which aimed to discipline religious life. According to the Constitutions, slaves also had the right to the Christian sacraments and the masters, as "good Catholics," were supposed to baptize them (Torres-Londoño, 2006).

In spite of its political force, the Catholic church had a precarious institutionality throughout the territory (Pereira das Neves, 2009). Registration norms were commonly reconfigured and locally adapted. In the first "book of deaths" of the São Leopoldo Colony's Catholic congregation (1827-1878), for example, we can see that the priests tended to follow the canonical model (Vide, 1853, p.292), mentioning the name and age of the deceased and whether he or she received, as required, the last sacramental rites. However, many priests also added presumed causes of death, something that was not mandated. This local adaptation can also be found in the Lutheran parish registers, thus providing scholars with important data on vernacular diagnostic cultures (see also Scott, Scott, Bassanezzi, 2014).

Like the Catholics, Lutherans also recorded the baptisms of slaves. These surprising records reveal how widespread enslaved labor was in the German settlements, even though a Provincial law from 1850 had prohibited immigrants from owning slaves (Moreira, Mugge, 2014, p.17). The Lutheran parish register of Hamburgo Velho lists the baptisms of fifty-one enslaved children between 1846 and 1871 (when the "Law of the Free Womb" granted freedom to all children born to slaves, see: Chalhoub, 2011): all children received the surname of their masters, unlike in Catholic practice (Woortman, 1995).

Compared to Catholics, Lutheran free children were given more godparents. While Catholic communities, following the Constitutions, tended to name only one godfather and one godmother for each child, in the Lutheran church books we noticed a significant increase over time in the number of godparents named (from one pair to three pairs). This practice could reflect original German traditions of newly arrived immigrants (Alfani, Gourdon, 2012) or the strategies of families to expand their social networks (Mugge, 2012).

After an initial visit to local Lutheran parishes and our examination of their "old church books," we developed a study of mortality and morbidity. We examined the registers of Sapiranga (1858-1880) (transcribed and translated by the local genealogist Ernani Haag), and of Campo Bom (1850-1880), Dois Irmãos (1850-1880), Hortêncio (1858-1880), Picada 48 (1850-1880), and Picada Café (1851-1880) ${ }^{9}$ - all transcribed and organized by the local genealogist Gaspar Stemmer and his research team. ${ }^{10}$ We studied all these registers in PDF format along with the photographed originals. Before proceeding with our data entry, we systematically crosschecked registries and found the transcriptions and translations of the originals to be largely accurate. We extracted all available information on births/ baptisms (Getaufen) and deaths/burials (Beerdigungen), standardized all German names into Portuguese (to facilitate complex analysis, Bauer, 2016), and created our own databank using MS Excel. In addition, we collected qualitative data on presumed causa mortis when recorded in the death/funeral entries. 


\section{Findings}

\section{Births/Baptisms}

Combined, the Lutheran communities of Sapiranga, Campo Bom, Dois Irmãos, Picada 48, Hortêncio, and Picada Café recorded 5,230 births/baptisms between 1850-1880 - an average of 168.71 births per year.

Graph 1: Number of births/baptisms in the Lutheran Communities of Campo Bom, Dois Irmãos, Picada 48, Picada Café, São José do Hortêncio, and Sapiranga per year, 1850-1880

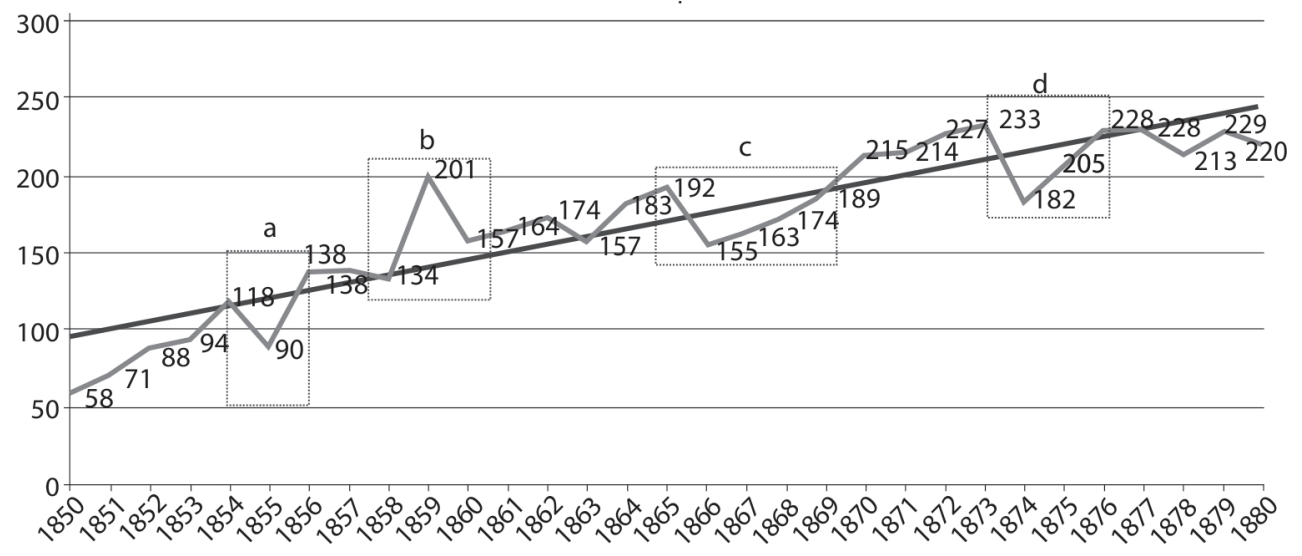

Source: Lutheran parish registers.

Graph 1 shows a systematic linear increase in the number of births/baptisms through time in these communities. Four key moments impacted this linear upward trend (see areas a, b, c, d), indicating the possible influence of external factors.

The first significant decline in childbirth occurred around 1855 (area a). Archival sources indicate that a major cholera epidemic found its ways into the Province of São Pedro do Rio Grande do Sul, also besetting the São Leopoldo Colony (Witter, 2007). Officials reported the outbreaks' deadly impact in the region, which could have impacted childbirth. In his 1856 annual report, the President of the Province, Barão de Muritiba, informed his successor that the number of victims of the cholera epidemic in Rio Grande do Sul remained "unknown." Yet, he estimated that "at least one third of the population" of the places where the infection was detected (such as the colonies of São Leopoldo) "suffered from this dreadful misfortune" (Muritiba, 1856).

The significant increase in the number of childbirths in 1859 (area b) corresponds to the addition of the newly-founded Lutheran communities of Sapiranga and Hortêncio to our dataset. In their first year of registration of births/baptisms, these communities already showed a high number of births: evidence of the fecundity and family planning of young couples in these frontier settlements.

There are two other periods when births sharply decreased: the years of 1866 and 1874, followed by subsequent increases (areas c and d). These declines could be related to war. First, there was the Paraguayan War (Mugge, 2016; Doratioto, 2002). Beginning in 1864, 
hundreds of single and married men from the colonies were recruited into the National Army and sent to the warfront. The bloody war lasted until 1870, when soldiers gradually returned from the battlefields, either resuming their married lives or entering the marriage market. As we can see in the following upward trend, these communities experienced a boom in childbirths that lasted until 1873, reaching a peak of 233 births that year. Then came the Mucker War of 1874. The intra-ethnic conflict not only led to a high number of casualties in region (Domingues, 1977; Amado, 1978), but also significantly impacted family life, including reproductive patterns.

\section{Deaths/Funerals}

A total of 943 deaths were recorded in the Lutheran communities of Campo Bom, Dois Irmãos, Hortêncio, Picada 48, Picada Café, and Sapiranga between 1850 and 1880: an average of 30.4 deaths per year. In $46.1 \%$ of the funeral entries (435 of 943), the clergy or community representatives inscribed a presumed causa mortis.

Table 1: Deaths in the Lutheran Communities of Campo Bom,

Dois Irmãos, Hortêncio, Picada 48, Picada Café, and Sapiranga, 1850-1880

\begin{tabular}{lccccccc}
\hline Communities & $\begin{array}{c}\text { Campo } \\
\text { Bom }\end{array}$ & $\begin{array}{c}\text { Dois } \\
\text { Irmãos }\end{array}$ & Hortêncio & Picada 48 & $\begin{array}{c}\text { Picada } \\
\text { Café }\end{array}$ & Sapiranga & Total \\
\hline Number of Deaths & 124 & 308 & 72 & 113 & 133 & 193 & 943 \\
\% of Total Deaths & $13.2 \%$ & $32.7 \%$ & $7.6 \%$ & $12 \%$ & $14.1 \%$ & $20.5 \%$ & $100 \%$ \\
$\%$ Male & $62.9 \%$ & $55.2 \%$ & $52.8 \%$ & $48.7 \%$ & $48.1 \%$ & $53.9 \%$ & $54 \%$ \\
$\%$ Female & $37.1 \%$ & $44.8 \%$ & $47.2 \%$ & $51.3 \%$ & $51.9 \%$ & $46.1 \%$ & $46 \%$ \\
\hline
\end{tabular}

Source: Lutheran parish registers.

As expected, the older and populous colony of Dois Irmãos registered the highest number of deaths. Meanwhile, the smaller, younger settlement of Sapiranga also showed a surprisingly high number of deaths (compared to the communities of Picada Café and Picada 48, which were similar in size and had a slightly older population). Overall, male mortality was higher than female mortality (54\% vs. $46 \%$ ). In two communities - Picada 48 and Picada Café - there was a slight predominance of female mortality, which might speak to the specific population structure of these small settlements.

Dead children

Our analysis of the distribution of deaths according to age groups revealed that 239 infants (0-1 years) died between 1850-1880 in these six communities, making up one fourth of all recorded deaths (25.3\%). The sex ratio in this age group (54.8\% males vs. $45.2 \%$ females) was in line with the trend of the overall recorded deaths.

This set of communities also had a high percentage of deaths in the age group 1-4 years: $18.1 \%$ of the total deaths, ranging from $13.7 \%$ in Campo Bom to $17.6 \%$ in São Leopoldo and $21.4 \%$ in Dois Irmãos. 
When combining the deaths of all infants and children (0-14 years) in these six communities, we found that this extended age bracket corresponded to more than half $53.1 \%$ - of all recorded deaths (501 out of 943). ${ }^{11}$ The highest percentage of child deaths were found in the communities of Sapiranga (59.1\%) and Picada Café (60.2\%). In other words, about six of ten funerals in these communities were for infants and children.

Infant mortality

In order to estimate the infant mortality rate for this micro-region, we correlated the deaths of children under one year of age within a given period with the births/baptisms from that period. We performed this exercise by dividing the reference period (1850-1880) into quinquennials.

Graph 2 - Estimated infant mortality rates in the Lutheran communities of Campo Bom, Dois Irmãos, Picada 48, Picada Café, São José do Hortêncio, and Sapiranga by quinquennials, 1850-1880

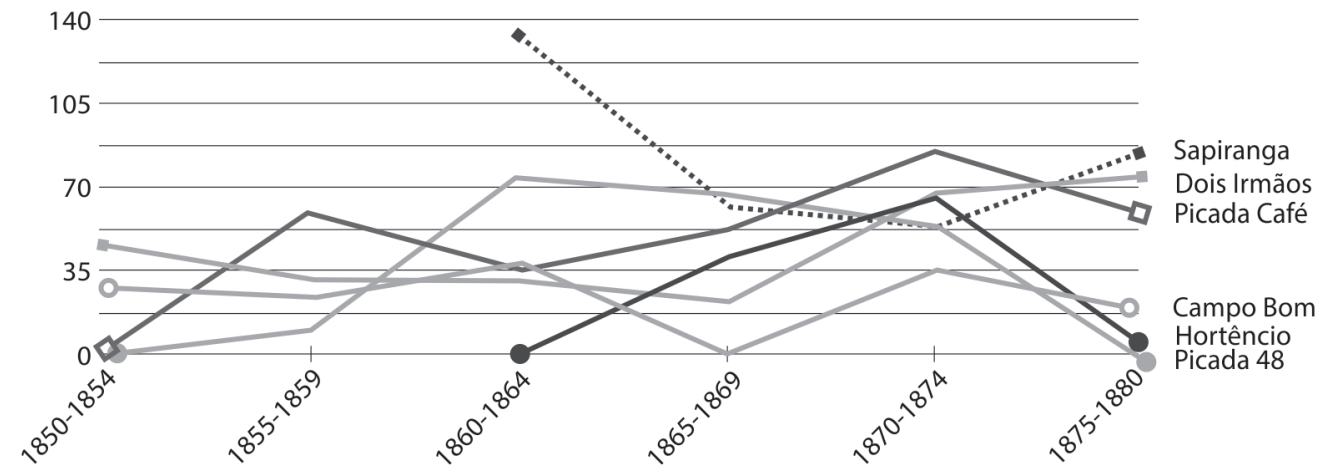

Source: Lutheran parish registers.

The high infant mortality rate (135 per 1,000 live births) in the community of Sapiranga during the 1860-1864 quinquennial stands out. This finding might speak to the inhospitable environment of this frontier settlement, where young families struggled to make their livelihoods (Magalhães, 2003). The first group of young families (the children of pioneer immigrants) arrived in the 1850s, establishing a Lutheran congregation in 1858. Surrounded by virgin forests, this was indeed an area of difficult access. People had no formal medical assistance, and their participation in commerce was still in its early stages.

A close reading of the registries of the fifteen infants (0-1 years) who died in Sapiranga between 1860-1864 shows that ten of them died in their first month of life (66.6\%). No causes of death were registered. Interestingly, seven of these fifteen infants were the firstborn in their families and two of them were orphans. We can infer that this neonatal mortality was not the result of specific diseases but of endogenous causes such as congenital defects, obstetric traumas, low birth weights and maternal deaths (Lee, Marschalck, 2002, p.570).

In contrast to Sapiranga, the communities of the older settlements of Campo Bom and Dois Irmãos had better infrastructure, more intergenerational households, and a greater number of health practitioners (experienced midwifes, pharmacists, and lay doctors) (Tramontini, 2000; Mugge, 2012). This reality could have impacted the comparatively 
lower (and by and large steady) infant mortality rate in these communities. In Dois Irmãos, for example, we identified seven deaths of infants (0-1 years) between 1860 and 1864, and only two of them died in their first month of life (28.6\%).

In comparing the evolution of infant mortality in all six communities for the period 1850-1880 we identified a certain seasonality, with a significant peak in the quinquennial 1870-1874. This peak occurred in at least four of the six communities - Dois Irmãos, Hortêncio, Picada Café (which reached their highest infant mortality rate in the period), and Campo Bom. In the communities of Picada 48 and Sapiranga, infant mortality stayed at a similar level to the previous quinquennial.

\section{Deceased young adults}

We counted all the deaths/funerals of women and men aged 15-39 years (reproductive age for women and military age for men) in the six communities of our micro-region. Between 1850-1880, 141 deaths were recorded for this age group (15\% of the total 943).

In combining the 141 deaths of men and women from this age group with the 501 deaths of children (0-14 years), we found that over two-thirds $(68.1 \%)$ of the deceased in these communities were young and of re/productive age. In other words, these communities overwhelmingly buried young adults and their progeny.

Deaths of men in military age

The six communities recorded the passing of 69 males of military age (15-39 years) between 1850 and 1880 - that is, $7.3 \%$ of all reported deaths.

If we consider males of all ages, $13.6 \%$ of them died at this young adult stage. Here we also noted significant local differences. While in Picada Café there were only three male deaths in this age group (out of a total of 64 male deaths, or 4.7\%), in Campo Bom there were 15 (out of a total of 78, or 19.2\%). Meanwhile, in Sapiranga, 12 of the 104 men $(11.5 \%)$ who died belonged to the age group 15-39 years.

In Dois Irmãos, 12 of the 21 registries of male deaths made reference to possible causes of death. Along with references to bacterial infections (from tuberculosis to enteritis), we found multiple allusions to symptoms, such as convulsions and diarrhea. External events caused the deaths of at least three men there: one "drowned," one was "attacked by killer bees," and one died after his "arm was crushed in a work-related accident." One man also died in military duty, "fighting the Mucker" in 1874.

In Sapiranga, we found a similar pattern: 7 of the 12 recorded deaths of males 15-39 years of age mentioned possible causes of death. Here most of the deaths were linked to infections (syphilis, dysentery, typhus) and accidents (drowning). There was one reference to a soldier who died on the Paraguayan warfront. In the nearby community of Campo Bom, 6 of the 15 registries of male deaths from this age group mentioned medical causes: measles, tuberculosis, encephalitis, gastrointestinal problems, and acute nervous fever. Four also mentioned external factors: one "drowned," one "died in the Paraguayan War," one was "killed by the Mucker," and one was killed by "a careless shot from a neighbor." 
Maternal death

Contrary to the general mortality trend ( $46 \%$ women vs. $54 \%$ men), more women than men died in the age group $15-39$ years (51.1\% vs. $48.9 \%)$. At the individual community level, we can see that female mortality was particularly high in Sapiranga (60\% vs. 40\%) and Picada Café (76.9\% vs. 23.1\%).

While men ages 15-39 died of myriad causes, we found that a great number of women in this age group across all communities shared the same cause of death: childbirth. Attuned to the randomness in the pastoral reporting of causes of death (less than half of the entries included such causes), we crosschecked each of the seventy-two women of reproductive age who died during 1850-1880 with the birth/baptism registries of that period.

We found that at least 27 women in our micro-region died from birth-related consequences, i.e. more than a third (37.5\%) of the women of reproductive age (72) who died between 1850 and 1880 .

A micro analysis illuminates how widespread and impactful maternal death was for households in this countryside. For example, of the 89 Lutheran women who died in Sapiranga between 1858 and 1880, 21 were of reproductive age (23.6\%). Eighteen of them were married and three were single (aged sixteen, twenty-one, and twenty-three, and without causes of death reported). We found that at least half of the married women there died of childbirthrelated complications, their ages ranging from twenty-two to thirty-eight years old. The birth/baptismal crosschecking was essential to unearth this fatal reality, as only three of the nine cases of death had been recorded as related to childbirth, such as the thirty-year-old Carolina Harz, who died on September 24, 1877, of "postpartum convulsion." Notably, four of these eighteen married women died a year after giving birth, as was the case of twentythree-year-old Elisabeta Steil, who died on July 4, 1873 "leaving two small children."

In the neighboring, older Lutheran community of Campo Bom, 46 women died between 1850 and 1880. Eight (17.4\%) were of reproductive age, four were married and four were single. At least two of the married women died from childbirth-related complications. The twenty-year-old Elisabeta Voss, for example, died on September 9, 1876, while "reposing from her first delivery," and the eighteen-year-old Eva Guilhermina Sperb died on December 19,1880 , nine days after giving birth (the pastoral entry says that "she died of Tuberculosis and left a child"). Intriguingly, three of the four single women died in their teens (at ages fifteen, seventeen, and eighteen) and none of them had a recorded cause of death.

In the western colony of Hortêncio, we found that 34 Lutheran women died between 1858 and 1880, and that eight of them (23.5\%) were of reproductive age (five were married and three were single). Among those married, three died from complications related to childbirth. Two sisters, Rosalina Papke and Guilhermina Papke, died shortly after delivery, less than a year apart: Rosalina passed away on August 8, 1872 and Guilhermina on January 22, 1873 - both of "nervous fever," as the parish registry declares.

In the community of Picada 48, 58 women died between 1850 and 1880 . Seven (12.1\%) were of reproductive age (four were married and three were single). Of this group, only the thirty-five-year-old Elisabeta Lorenz died after delivery - "anemia \& dropsy \& puerperal fever," according to the lay pastor João Jorge Klein. Tragically, the eighteen-year-old Louise 
von Mühlen (born Hepp) died on August 8, 1868 - "dragged by a scared horse" - six months after giving birth to a baby boy.

In Picada Café, 69 women died between 1851 and 1880. Ten (14.5\%) were of reproductive age (eight were married and two were single). Three of the married women died from childbirth related complications. On November 26, 1875, for example, Pastor Carlos Hunsche baptized the five-day-old Heinrich Leonhardt "in the house of his parents, by his mother's coffin." The thirty-seven-year-old Prussian-born Maria Catarina Weber, a mother of four, had died from "hard labor" the day before. As in other communities, here too we found two single women in their teens without any record of cause of death. A twentysix-year-old woman also died sixteen months after giving birth.

In the older colony of Dois Irmãos, the high number of maternal deaths resembles the figures we found in Sapiranga: nine married women died of childbirth complications among the group of eighteen women of reproductive age (fourteen were married and four were single) who passed away between 1850 and 1880 (from a total of 128 deceased women). Here, at least four pregnancies ended in stillbirth and maternal death: the twenty-year-old Elisabeta Kussler, who died on May 8, 1852, "of a difficult birth... giving birth to a dead child and leaving his first and only son, a boy of almost 2 years;" the seventeen-year-old Maria Engelmann, who died on February 19, 1858, "from a disastrous birth;" the twentyyear-old Elisabetha Philippina Klein (born Lampert), who died on April 1, 1863, "from childbirth;" and the twenty-one-year-old Lisetta Geiger (born Berg) who died on August 25,1872 , after the birth of her second child, who had been "brought dead into the world."

On July 7, 1874, at the height of the Mucker war, pastor Johann Friedrich Brutschin recorded that the thirty-three-year-old Anna Maria Becker, mother of six children, "died instantly of terror caused by the incendiary [Mucker] killers from Sapiranga."

Among the four single young women who died in Dois Irmãos without a record of cause of death, we found the fifteen-year-old "servant slave Eva [Blauth]:" "daughter of Anton and Eva [Blauth] who were owned by Mr. Jakob Blauth and are now free ... and was buried in the cemetery of this settlement."

\section{Final considerations}

A precarious living environment, suffused with both fertility and untimely death: this is the picture that emerges from our analysis of Lutheran parish registers of the northern settlements of the Colony of São Leopoldo (1850-1880). Rampant child and maternal death assailed this frontier zone, and everyday life was punctuated by infections and accidents, along with epidemic outbreaks (e.g. cholera and smallpox) and war (international and civil conflict). The menace of death haunted households in these remote yet interconnected German-Brazilian farming communities. Strikingly, we found that $68.1 \%$ of the deceased in this micro-region (501 of a total number of 903) were infants, children, and young adults (i.e., seven out of ten deaths). Our findings also show that in this context, child death extended far beyond the neonatal period and the first year of life. Between 1850 and 1880, more than half (53.1\%) of all deaths recorded were of infants and children (0-14 years). 
As an analytical exercise, we compared the infant mortality rates found in our microregion with the limited studies on infant mortality in eighteenth- and nineteenth-century Brazil (Santos, 2013, p.68; Campos, 2011, p.222-224). The highest rate of 135 per 1000 live births, found in the settlement of Sapiranga, is close to the rate of 114 per 1,000 live births found in the village of Curitiba (1785-1798) (Burmester, 1986, p.295-308), and significantly lower than the rate of 240 found in Vila Rica, Province of Minas Gerais (1799-1801) (Costa, 1976, p.241-262). The colonies' infant mortality rates were significantly lower than those found in the capital of Rio de Janeiro at a time when, according to historian Maria Luiza Marcílio, a true "genocide of children" was taking place: 206 in 1864, 578 in 1873, and 645 in 1875 (per 1,000 live births) (Marcílio, 2017, p.107).

We expanded this exercise to demographic studies of infant mortality in mid-19th century Germany. The rates in rural and pre-industrial regions, where the majority of immigrants originated, were much lower than the rates in large cities, which recorded infant mortality rates between 150 and 380 per 1000 live births (Lee, Marschalck, 2002, p.558). Scholars credit these lower rates (which resemble that of Sapiranga during 18601864) to the frequency and duration of breastfeeding (related to women's domestic, agricultural forms of work) as well as to relatively better sanitary conditions and access to food (Mühlichen, Scholz, Doblhammer, 2015, p.194-195). This could also be said about our southern Brazilian micro-region when compared to the insalubrious reality of the imperial capital Rio de Janeiro.

The omnipresence of premature death must have been intensely felt across households and neighborhoods in these German-Brazilian rural communities, reshaping people's ideas of wellbeing and their memorialization practices (Blume, 2015). ${ }^{12}$ One can only imagine the devastating emotional toll and adverse long term economic effects of an undeterred increase in infant mortality, and how, in order to ward off early death, each new family had to develop, with the aid of elders and neighbors, their own kind of home-based care, to be supplemented by the medicine of local healers.

In analyzing the evolution of child mortality in all six Lutheran communities, we noted a significant spike in the quinquennial 1870-1874. Intriguingly, this peak coincides with the central dates of the religious-therapeutic movement of the Mucker. Starting in 1868, people from all over the northern colonies flocked to the home of Jacobina Mentz and João Jorge Maurer, located at the foothills of the Ferrabrás Mountain in Sapiranga, in search of therapies for themselves and their families (Amado, 1978; Biehl, 2008).

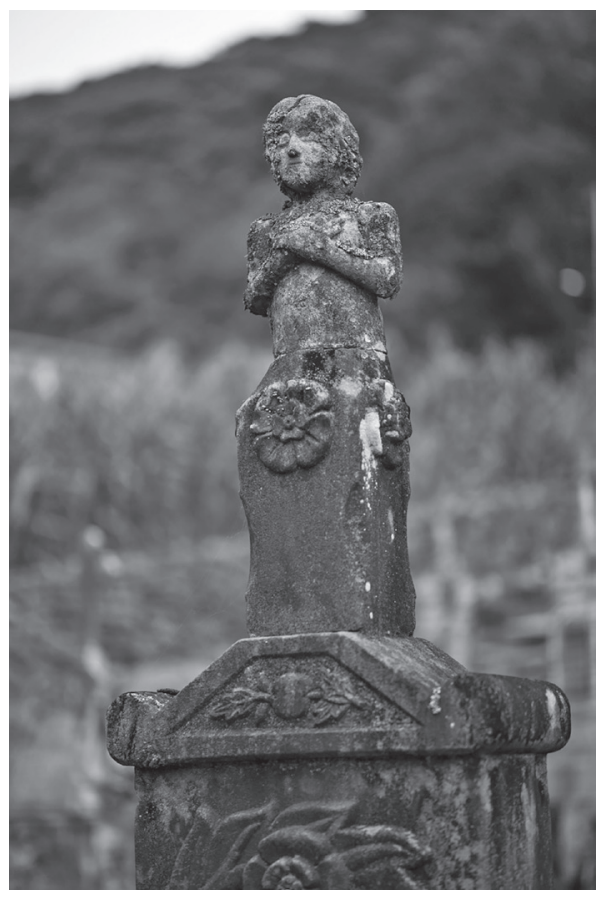

Figure 4: A child's grave in the Lutheran cemetery of Walachai (part of Dois Irmãos in the 19th century) (Courtesy of Torben Eskerod) 
Had we come across a plausible correlation between the considerable increase in infant mortality and the growing pilgrimage to the Maurers' home in this pre-Mucker conflict period? Might people's generalized affliction, and a rampant increase in child mortality in particular, have been at the center of the crystallization of a therapeutic-religious space later stigmatized and hunted down as Mucker quackery?

Contrary to general mortality trends in this region, more women of reproductive age died than men in military age (15-39 years). This was largely due to maternal death: $37.5 \%$ of women of reproductive age died due to childbirth-related complications. This reality must have devastated families, influenced child mortality, and significantly affected the mindful bodies of younger women. We also found a surprisingly high number of young single women (14 out of 72 registries), without references to causes of death, like the fifteenyear-old enslaved Eva from Dois Irmãos. Facing the limits of available evidence, we can only wonder as to how and why these young women's lives ended so prematurely. Were these also cases of young maternal deaths and stillbirths? Or perhaps of a final agency in withdrawing from captivity and unbearably violent domestic worlds?

Men of military age died of various causes, ranging from infectious diseases to workrelated accidents or war-related injuries. During the Paraguayan war (1864-1870), hundreds of young men from the São Leopoldo colonies were recruited and sent to the front (Mugge, 2012). The parish registers we studied occasionally reported on the German-Brazilian war casualties (Becker, 1968). Families held memorial services in the absence of the bodies of their departed loved ones. ${ }^{13}$

We found references to possible causa mortis in less than half (46.1\%) of the parish registers analyzed. Most people died without a precise medical diagnosis. The existing references were most likely based on information retrieved from grieving families or neighbors and by and large allude to symptoms. The most commonly cited cause of death is Krämpfe ("convulsions"), suggesting a scenario in which families witnessed febrile seizures before the passing of a loved one. These references are a rich resource for future studies on the dissemination of medical categories and treatments in this Southern countryside and on vernacular classificatory systems.

A comparison between the mortality patterns found in our rural region and more urbanized areas is in order. As a next step in our overall research project, we plan to analyze the records of births/baptisms and deaths/funerals in the Lutheran communities of São Leopoldo, Hamburgo Velho, and the provincial capital Porto Alegre. We want to test hypotheses about rural-urban disparities in infant mortality rates, as suggested by scholarship on nineteenth-century Europe, where urban settings had higher rates due to maternal work outside the home, decreased frequency of breastfeeding, and circulation of endemic diseases and epidemics, despite greater access to public health measures by the State (Laux, 1989; Gehrmann, 2011). A comparison of mortality patterns between the Lutheran populations we studied and their Catholic neighbors is also in order. Such a study could investigate whether denominational belonging might have distinctly impacted reproduction and mortality patterns, as argued by a growing number of demographers and historians working in nineteenth-century Europe (Mühlichen, Scholz, Doblhammer, 2015). 
Historical anthropologists, historians, and demographers can indeed join efforts in identifying and exploring the potentials of hitherto insufficiently studied communal archival sources. While unearthing grassroots archives, our collaborative efforts enlarge our knowledge of the environmental and social determinants of life chances in frontier zones, while also illuminating people's arts of living and healing.

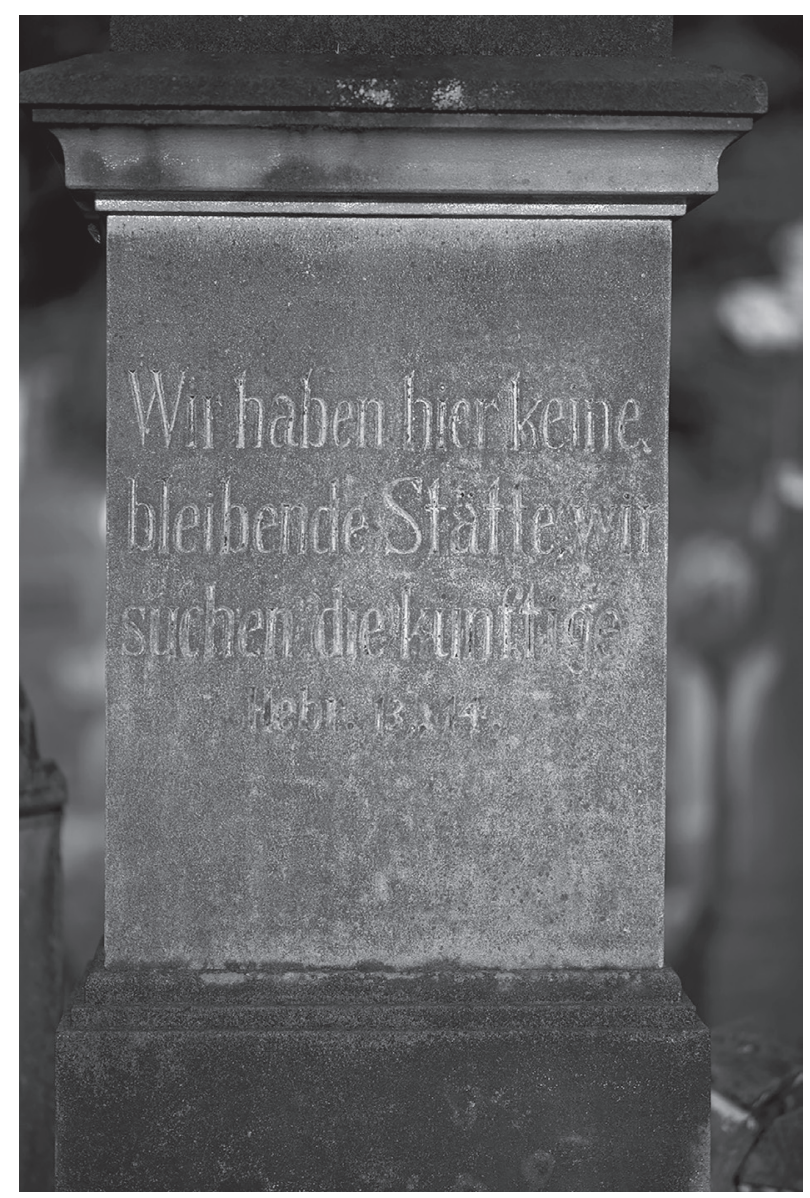

Figure 5: "Here, we don't have an enduring place, we look for a future one" - 19th century tombstone in the Lutheran cemetery of Canto Bayer (then part of São José do Hortêncio) (Courtesy of Torben Eskerod)

\section{ACKNOWLEDGEMENTS}

We are grateful to Princeton University's Center for Health and Wellbeing and the Woodrow Wilson School of Public and International Affairs for supporting this study. We benefited immensely from conversations with colleagues associated with the Brazil LAB (Luso-Afro-Brazilian Studies) at the Princeton Institute for International and Regional Studies. We also want to express our deepest gratitude to the Lutheran communities who kindly facilitated our archival research. We are indebted to Erny Mugge, Iria Hauenstein, Tom Vogl, Ana Silvia Volpi Scott, Sergio Nadalin, Sandro Blume, Monica Karawejczyk, Fernando AcostaRodriguez, and Naomi Zucker, for their wonderful help. Special thanks to the Danish artist Torben Eskerod who joined us in the field, and whose beautiful photographs are integral to this essay. Thank you also to the editorial team of História, Ciências, Saúde - Manguinhos and to the anonymous reviewers for their valuable insights. 


\section{NOTES}

${ }^{1}$ This particular study is part of anthropologist João Biehl's larger investigation of everyday life in the German colonies of southern Brazil before and immediately after the Mucker war in 1874 (Biehl, 2008). See: <http://joaobiehl.net/manuscripts/the-valley-of-lamentation/>.

2 The congregation of Dois Irmãos was founded in 1827, Campo Bom in 1828, Picada 48 in 1850, Picada Café in 1851, and Sapiranga (then called Leonerhof) and São José do Hortêncio in 1858.

${ }^{3}$ According to the 1854 report produced by the ex-director of the São Leopoldo Colony, Dr. João Daniel Hillebrand, Lutherans made up 58\% of the population of the region at that time (Hillebrand, 1924).

${ }^{4}$ These records would be the basis for the pioneering European studies of mortality and life expectancy (Kundmann, 1737; Sussmilch, 1761).

${ }^{5}$ Relatório do Presidente da Província de S. Pedro do Rio Grande do Sul João Lins Vieira Cansansão de Sinimbu, na abertura da Assembleia Legislativa Provincial em 2 de outubro de 1854. Porto Alegre: Typ. do Mercantil, 1854.

${ }^{6}$ See Decree 3.069, article 52, which regulated the registry of vital events of "people who held a religion other than the State religion" (Brasil, 17 abr. 1863; Registro..., 1861-1889).

${ }^{7}$ The microfilms of these parish registers are available through the Family History Library. See $<$ http:// www.worldcat.org/title/kirchenbuch-1858-1962/oclc/866087500>.

${ }^{8}$ The idea of a unifying synod would only get prominence in the late 1860 s, after the systematic arrival of German ordained pastors (Hunsche, 1983; Dreher, 1984).

${ }^{9}$ The Lutheran community of Picada Café went through a split in 1861 and reunification in 1891, generating two different books (1A and 1B). In our study, we consider both books as belonging to one larger community.

${ }^{10}$ See the GenealogiaRS website: <https://www.genealogiars.com/livros>.

${ }^{11}$ Overall, there was a small predominance of male child deaths (57\% vs $43 \%$ ) and the gender differences between the various communities followed the same trend mentioned above.

${ }^{12}$ Collective family work was the norm of every small landholding (Petrone, 1982) and children played an important role in the sustenance of the domestic economy and the family's social integration (Woortman, 1995).

${ }^{13}$ See Biehl and Mugge, forthcoming, for an analysis of the role of German-Brazilian communities in the sustenance of patriotism in the bloodiest of South America's wars, and how, in the war's aftermath, some people back home found ways to transcend the specter of death, while others learned to kill their neighbors in impunity (during the Mucker War). See also Sant'Ana (2004).

\section{REFERENCES}

ALFANI, Guido; GOURDON, Vincent.

Spiritual kinship and godparenthood: an introduction. In: Alfani, Guido; Gourdon, Vincent. Spiritual kinship in Europe, 1500-1900. London: Palgrave and Macmillan. p.1-46. 2012.

AMADO, Janaina.

Conflito social no Brasil: a revolta dos "Mucker", Rio Grande do Sul, 1868-1898. São Paulo: Símbolo. 1978.

BAUER, Jean.

Republican of letters: the early American Foreign Service as information network, 1775-1825. Dissertation (History PhD) - University of Virginia. 2016.

BECKER, Klaus.

Alemães e descendentes do Rio Grande do Sul na Guerra do Paraguai. Canoas: Editora Hilgert. 1968.
BIEHL, João.

Jammerthal, the valley of Lamentation. The Mucker war: a contribution to the history of local Germanism in 19th century southern Brazil. Tese (Doutorado em Estudos Sociais da Religião) - Graduate Theological Union, Berkeley. 1996a.

BIEHL, João.

Uma tribo que pensa e negocia em alemão. In: Gertz, René; Fischer, Luiz A. Nós, os teutogaúchos. Porto Alegre: Editora da UFRGS. p.227236. $1996 \mathrm{~b}$.

BIEHL, João.

The Mucker war: a history of violence and silence. In: Good, Mary-Jo; Hyde, Sandra; Good, Byron. Postcolonial Disorders. Berkeley: University of California Press. p.279-308. 2008. 
BIEHL, João.

A guerra dos imigrantes: o espírito alemão e o estranho Mucker no Sul do Brasil. In: Sousa, Edson (Org.). Colonização e psicanálise. Porto Alegre: Artes e Ofícios. p.148-168. 1999.

BLUME, Sandro.

Morte e morrer nas colônias alemãs do Rio Grande do Sul: recortes do cotidiano. São Leopoldo: Oikos. 2015

BRASIL.

Decreto n.3.069, de 17 de abril de 1863. Regula o registro dos casamentos, nascimentos e óbitos das pessoas que professarem religião diferente da do Estado. Disponível em: <http://www2. camara.leg.br/legin/fed/decret/1824-1899/ decreto-3069-17-abril-1863-555008publicacaooriginal-74026-pe.html>. Acesso em: 4 maio 2017. 17 abr. 1863.

BURMESTER, Ana Maria.

Contribuição metodológica para estimativas de mortalidade: Curitiba, século XVIII. In: Costa, Iraci del Nero da. Brasil: história econômica e demográfica. São Paulo: IPE. p.295-308. 1986.

CAMPOS, Katia.

"Sem dados não há demografia": uma proposta para a criação de um banco de dados demográficos e sua aplicação em uma paróquia mineira: 1760-1804. Tese (Doutorado em Demografia) - Universidade Federal de Minas Gerais, Belo Horizonte. 2011.

CHALHOUB, Sidney.

Visões da Liberdade: uma história das últimas décadas da escravidão na Corte. São Paulo: Companhia das Letras. 2011.

COSTA, Iraci del Nero da.

Análise da morbidade nas Gerais (Vila Rica, 1799-1801). Revista de História, v.54, n.107, p.241-262. 1976.

DICKIE, Maria Amado Schmidt.

Afetos e circunstâncias: um estudo sobre os Mucker e seu tempo. Tese (Doutorado em Antropologia) - Universidade de São Paulo, São Paulo. 1996.

DOMINGUES, Moacyr.

A nova face dos Muckers. São Leopoldo:

Rotermund. 1977.

DORATIOTO, Francisco.

Maldita guerra: nova história da Guerra do Paraguai. São Paulo: Companhia das Letras. 2002.

DREHER, Martin.

A religião de Jacobina. São Leopoldo: Oikos. 2017.

DREHER, Martin.

Igreja e Germanidade: estudo crítico da história da Igreja Evangélica de Confissão Luterana no Brasil. Porto Alegre: EST Edições. 1984.
EDVINSSON, Sören; GARDARSDÓTTIR, Ólöf; THORVALDSEN, Gunnar.

Infant mortality in the Nordic countries, 17801930. Continuity and Change, v.23, n.3, p.457485. 2008.

FARGE, Arlette.

The allure of the archives. New Haven: Yale University Press. 2013.

FOGEL, Robert W.

Economic growth, population theory, and physiology: the bearing of long-term processes on the making of economic policy. The American Economic Review, v.84, n.3, p.369-395. 1994.

FOUCAULT, Michel.

The lives of infamous men. In: Faubion, James (Ed.). Power, v.3. London: Penguin. p.155-175. 2000.

FRAGOSO, João.

Apontamentos para uma metodologia em história social a partir de assentos paroquiais (Rio de Janeiro, séculos XVII e XVIII). In: Fragoso, João et al. Arquivos paroquiais e história social na América Lusa, séculos XVII e XVIII: métodos e técnicas de pesquisa na reinvenção de um corpus documental. Rio de Janeiro: Mauad X. p.21-105. 2014.

GEHRMANN, Rolf.

Infant mortality in Germany in the 19th

Century. Comparative Population Studies, v.36, n.4, p.839-868. 2011.

GLAVATSKAYA, Elena; BOROVIK, Julia; THORVALDSEN, Gunnar.

Urban infant mortality and religion at the end of the nineteenth and in the early twentieth century: the case of Ekaterinburg, Russia. The History of Family. Disponível em: <http://dx.doi. org/10.1080/1081602X.2017.1341845>. Acesso em: 1 abr. 2017. 2017.

HILLEBRAND, João Daniel.

Relatório apresentado ao governo da Província pelo Dr. João Daniel Hillebrand, ex-diretor das Colônias. Revista do Archivo Publico do Rio Grande do Sul, n.15-16, p.337-439. 1924.

HUNSCHE, Carlos Henrique.

Protestantismo no Sul do Brasil. Porto Alegre: EST Edições; São Leopoldo: Editora Sinodal. 1983.

HUNSCHE, Carlos Henrique.

O biênio 1824/25 da imigração e colonização alemã no Rio Grande do Sul (Província de São Pedro). Porto Alegre: A Nação. 1975.

KUNDMANN, Johann.

Reflexiones über die Kranckheits- und Todten-

Listen, mit Medicinischen Anmerckungen begleitet. In: Kundmann, Johann C. (Org.). Rariora Naturoe \& Artis item in Re Medica, 
oder Seltenheiten der Natur und Kunst des Kundmannischen Naturalien-Cabinets, wie auch in der Artzeney-Wissenschaft. Breslau/ Leipzig: Ben Michael Hubert. p.1248-1312. 1737.

LAUX, Hans-Dieter.

The components of population growth in Prussian cities, 1875-1905 and their influence on urban population structure. In: Lawton, Richard; Lee, Robert. Urban population development in western Europe from the late eighteenth to the early-twentieth century. Liverpool: Liverpool University Press. p.120148. 1989.

LEE, W. Robert; MARSCHALCK, Peter. Infant mortality in Bremen in the 19th century. History of the Family, v.7, p.557-583. 2002.

MAGALHÃES, Dóris Rejane.

Terra, senhores, homens livres, colonos e escravos na fronteira do Vale do Sinos. São Leopoldo: Unisinos. 2003

MARCÍLIO, Maria Luiza.

A história em todos os seus sentidos: demografia histórica e questões contemporâneas. Belo Horizonte: Editora PUC Minas. 2017.

MOREIRA, Paulo; MUGGE, Miquéias. Histórias de escravos e senhores em uma região de imigração europeia. São Leopoldo: Oikos. 2014.

MUGGE, Miquéias.

Senhores da guerra: elites militares no sul do Império do Brasil. Tese (Doutorado em História Social) - Universidade Federal do Rio de Janeiro, Rio de Janeiro. 2016.

MUGGE, Miquéias.

Prontos a contribuir: guardas nacionais, hierarquias sociais e cidadania (Rio Grande do Sul, século XIX). São Leopoldo: Oikos \& Unisinos. 2012.

MÜHLICHEN, Michael; SCHOLZ, Rembrandt; DOBLHAMMER, Gabriele.

Social differences in infant mortality in 19th century Rostock: a demographic analysis based on church records. Comparative Population Studies, v.40, n.2, p.191-216. 2015.

MURITIBA, Barão de.

Relatório com que o Conselheiro Barão de Muritiba entregou a presidência da província de S. Pedro do Rio Grande do Sul ao Exmo. Sr. Presidente e Comandante das Armas, conselheiro e general Jeronimo Francisco Coelho no dia 28 de abril de 1856. Porto Alegre: Typ. do Mercantil. 1856.

NADALIN, Sérgio. Imigração e família, segunda metade do século XIX. Revista Latinoamericana de Población, v.8, n.14, p.31-55. 2014.
NADALIN, Sérgio.

A origem dos noivos nos registros de casamento da Comunidade Evangélica Luterana de Curitiba, 1870-1969. Dissertação (Mestrado em História) - Universidade Federal do Paraná, Curitiba. 1974.

NEVES, Guilherme Pereira das.

A religião do Império e a Igreja. In: Grinberg, Keila; Salles, Ricardo (Org.). O Brasil imperial, v.1: 1808-1831. Rio de Janeiro: Civilização Brasileira. p.377-428. 2009.

PAIVA, Clotilde Maria et al.

Publicação crítica do Recenseamento Geral do Império do Brasil de 1872. Belo Horizonte: NPHED/UFMG. 2012.

PETRONE, Maria Thereza.

O imigrante e a pequena propriedade. São Paulo: Brasiliense. 1982.

PETRY, Leopoldo.

O episódio do Ferrabraz: documentos para o estudo da história dos "mucker" do Ferrabraz. São Leopoldo: Rotermund. 1957.

\section{REGISTRO...}

Registro de eleições e nomeações de pastores. Documentos Eclesiásticos. A-8.015. (Arquivo Histórico do Rio Grande do Sul). 1861-1889.

ROCHE, Jean.

A colonização alemã e o Rio Grande do Sul. 2 v. Porto Alegre: Editora Globo. 1969.

SANT'ANA, Elma.

Minha Amada Maria: cartas dos Mucker. Canoas: Editora da ULBRA. 2004.

SANTOS, Gracineide Pereira dos. Afinal, quantos éramos? Um estudo da mortalidade pretérita na Freguesia da Gloriosa Sant'Anna. Dissertação (Mestrado em Demografia) - Universidade Federal do Rio Grande do Norte, Natal. 2013.

SCOTT, Ana Silvia; SCOTT, Dario; BASSANEZI, Maria Silvia.

Mortality in the far south of Brazil: population of the Parish of Madre de Deus de Porto Alegre, 1772-1827. Paper presented in First Conference of the European Society of Historical Demography, 2014. Alghero. 2014.

SCOTT, Ana Silvia.

Famílias, formas de união e reprodução social no noroeste português (séculos XVIII e XIX). São Leopoldo: Oikos \& Editora Unisinos. 2012.

SEN, Amartya.

Mortality as an indicator of economic success and failure. The Economic Journal, v.108, p.1-25. 1998. 
SEYFERTH, Giralda.

Nacionalismo e identidade étnica: a ideologia germanista e o grupo étnico teuto-brasileiro numa cimunidade do Vale do Itajaí.

Florianópolis: Fundação Catarinense de Cultura. 1982.

SUSSMILCH, Johann.

Die göttliche Ordnung in den Veränderungen des men- schlichen Geschlechts, aus der Geburt, dem Tode und der Fortpflanzung desselben erwiesen. Zwote und ganz umgearbeitete Ausgabe. Berlin: Verlag des Buchladens der Realschule. 1761.

TORRES-LONDOÑO, Fernando.

As constituições do arcebispado da Bahia de 1707 e a presença da escravidão. In: Andreazza, Maria Luiza et al. (Org.). VI Jornada Setecentista. Conferências \& Comunicações. Curitiba: Cedope. p.275-282. 2006.

TRAMONTINI, Marcos Justo.

A organização social dos imigrantes: a colônia alemã de São Leopoldo na fase pioneira, 18241850. São Leopoldo: Editora Unisinos. 2000.

VIDE, Sebastião Monteiro da Silva. Constituições primeiras do Arcebispado da Bahia feitas, e ordenadas pelo Illustrissimo, $e$ Reverendissimo Senhor D. Sebastião Monteiro da Vide: propostas, e aceitas em o Synodo Diocesano, que o dito Senhor celebrou em 12 de junho do anno de 1707. São Paulo: Typographia 2 de Dezembro. 1853.

VÖGELE, Jörg; WOELK, Wolfgang. Public health and the development of infant mortality in Germany, 1875-1930. History of the Family, v.7, p.285-599. 2002.

WACHHOLZ, Wilhelm.

"Atravessem e ajudem-nos": a atuação da "Sociedade Evangélica de Barmen" e de seus obreiros e obreiras enviados ao Rio Grande do Sul (1864-1899). São Leopoldo: Sinodal. 2003.

WITT, Marcos.

Em busca de um lugar ao sol: estratégias políticas: imigração alemã no Rio Grande do Sul, século XIX. São Leopoldo: Oikos. 2015.

WITTER, Nikelen Acosta. Males e epidemias: sofredores, governantes e curadores no sul do Brasil (Rio Grande do Sul, século XIX). Tese (Doutorado em História) Universidade Federal Fluminense, Niterói. 2007.

WOORTMAN, Ellen Fensterseifer.

Herdeiros, parentes e compadres: colonos no Sul e sitiantes no Nordeste. São Paulo: Hucitec. 1995. 